\title{
Professional dynasties in the public consciousness of Russians
}

\author{
Oksana Posukhova ${ }^{1}$, and Lyudmila Klimenko ${ }^{1 *}$ \\ ${ }^{1}$ South Federal University, 344006, Rostov-on-Don, Russia
}

\begin{abstract}
The article discusses the features of the professional dynasties perception by various subgroups of Russian society population. The empirical basis of the analysis is the materials of sociological studies of Russian Center for Research, HeadHunters-company, scientists of Southern Federal University. The results of the surveys show that among Russians the attitude towards professional continuity in the family is not popular, although the phenomenon of professional dynasties is generally assessed positively. Against this background, a subgroup of the population appears in the amount of from a quarter to a one-third of all the respondents who indicate their desire or the desire of their parents to inherit professional status. Most often, they share the attitude towards the continuation of family traditions in the professional sphere by representatives of higher-paid professional groups (lawyers, programmers, representatives of the extraction and processing of raw materials, telecommunications and communications, construction and real estate). Based on the research materials of education and medicine workers, the dependence is confirmed that, with a decrease in status positions and a drop in the profitability of the profession, orientations toward continuing professional continuity in the family decrease.
\end{abstract}

\section{Introduction}

A professional dynasty is a social group localized in the production and socio-economic structure, characterized by kinship relations, in which several generations carry out their professional activities in one area. The development of professional dynasties is very often explained by the transfer of human capital. For posterity of professionals, the costs of acquiring the necessary skills and knowledge may be lower than for others who want to master this profession. High levels of continuity are often recorded among self-employed (Dunn \& Holtz-Eakin, 2000; Sørensen, 2007), entrepreneurs (Lindquist et al., 2015), representatives of licensed professions (Pelizzari et al. 2011), which can be explained by the transfer of not only the necessary competencies, but also the customer base development, business ties.

\footnotetext{
*Corresponding author: lucl@yandex.ru
} 
Professional dynasties in modern conditions have dual potential. On the one hand, they can be regarded as a social monopoly, limiting access to prestigious professional statuses. For example, in the Italian public sector, the son of an official has a $44 \%$ chance of being hired by the civil service, which the author of the study, Scoppa V. (2009), considers to be a direct manifestation of favoritism and nepotism. Another study found that nepotism affects the chances of young people to pass the qualification exams required for work in licensed professional fields (Aina \& Nicolett, 2014; Aina \& Nicolett, 2018). A study of the Canadian labor market found a positive relationship between the frequency of hiring a young person in the organization where his parent works and the income of the parent (Corak \& Piraino, 2011).

On the other hand, it is from them that primary professional socialization begins, which determines professional trajectories and constructive professional identity (Mansurov, 2017). Professional dynasties are gradually turning into stable groups of a professional stratification structure that reinforce social stratification. In addition, professional dynasties have become an integral element of specific professional organizations; affect the effectiveness of their work and further development.

\section{Formulation of the problem}

The dual nature of dynasty in the professional sphere determines the difference in the assessments of this phenomenon in public consciousness. This problem acquires particular significance in the context of different prestige for professions, factors of labor motivation, development and reproduction of the profession ethos. In the context of precariatization of Russian society, the problem of professional identity erosion and continuity is becoming increasingly important. A growing number of people lose confidence in the value of their work and suffer from uncertainty and legal insecurity in the field of their work (Klimenko \& Posukhova, 2018a).

Under these conditions, professional dynasty can minimize the negative consequences of precariatization due to the early professional socialization of dynasty members and the family capitalization of professional knowledge. But at the same time, such an indicator of precariatization as career prospects lack (Klimenko \& Posukhova, 2018b) and upward social mobility determines the destructive potential of professional dynasties in the form of status monopolization as an effective practice of self-preservation.

In this regard, the objective of this article is to analyze the perception of professional dynasties by various subgroups of the population of Russian society.

\section{Research method}

The study is based on an analysis of applied sociological research results:

1) The study of the Russian Center for the Study of Public Opinion (RCSPO) (a survey among 1600 people in 138 settlements in 46 regions, territories and republics of Russia) in 2008-2010 and HeadHunter (online survey among 3300 working Russians) in 2010;

2) A study by a team of scientists from the Southern Federal University, conducted with the support of the Russian Science Foundation (project "Professional Identity of Metropolis Residents in the Conditions of Pre-cariatization of Russian Society"). A survey among 2310 teachers of state comprehensive schools (948 of them in Moscow, 618 in Rostov-on-Don, 744 in Kazan) and 1270 doctors of state medical institutions (468 of them in Moscow, 400 in Rostov-on Don and 402 - in Kazan) in 2017-2018.

\section{Population' attitude towards professional dynasties}


The results of nationwide surveys show that the inhabitants of our country are generally positive about the existence of professional dynasties. More than half of the respondents agreed that labor dynasties were needed (55\% of the respondents in 2008 and $54 \%$ in 2010 collected the answer "yes" and "rather yes") (Fig. 1).

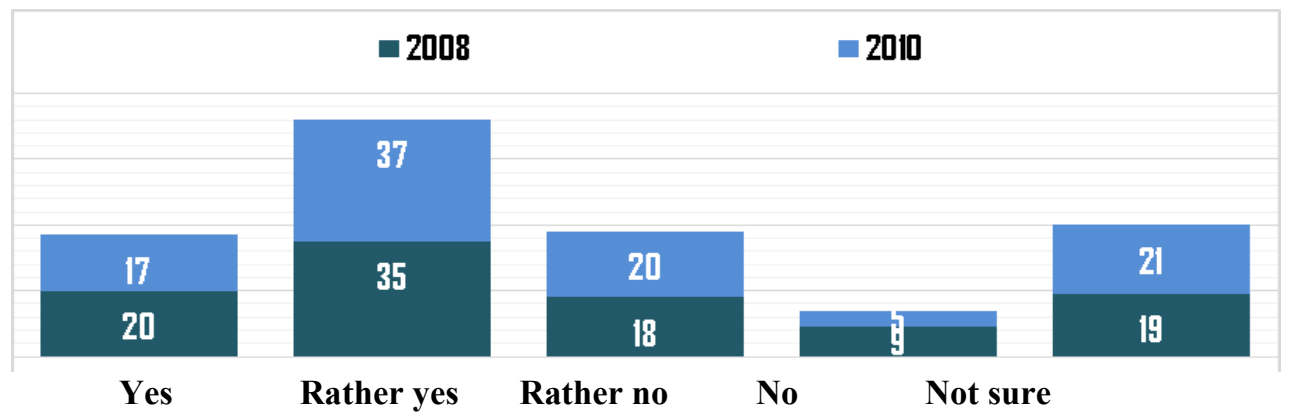

Fig. 1. Responses of the Russian population to the question "In general, do you think labor dynasties are needed?" (RCSPO survey, $\%)^{1}$

Moreover, not more than $3 \%$ of the Russians surveyed indicated that when choosing their profession they were guided by considerations of dynasty and followed family tradition. Most often, the decisive role was played by one's own hobbies and interests $(33 \%$ in 2008 and $32 \%$ in 2010), a combination of circumstances (29\% and $37 \%$ ), there was no choice $(12 \%$ and $15 \%)$, the wage level in profession $(11 \%$ and $8 \%)$, the demand for a specialty in the labor market ( $11 \%$ and $7 \%$, respectively).

More than half of the Russian population would not want their children to choose the same profession as theirs (56\% in 20018 and 59\% in 2010). At the same time, about a fifth of Russians share the attitude to continue the professional dynasty in the family $(20 \%$ and $23 \%$, respectively). In addition, the parents of the respondents in most cases also did not want their children to form professional continuity in the family. $48 \%$ said the options are "definitely not" and "probably not." But the third share of respondents (32\%) indicated the opposite. You can also fix that the higher the level of education, the more expressed is the desire of parents about the professional continuity of their children.

Most often, lawyers (49\%), programmers (45\%), representatives of the spheres of raw materials extraction and processing $(42 \%)$, telecommunications and communications $(39 \%)$, construction and real estate $(39 \%)$ share the attitude towards continuing family traditions in the professional sphere. Least of all these representations are typical for the restaurant and hotel business (20\%), sales and customer service (19\%), and administrative and business activities (14\%) (Russians do not want ..., 2010).

As you can see, in the most profitable areas of professional activity, orientation towards labor dynasty is more common. These indicators correspond to the research results of the Italian scientist S. Mocetti. He recorded a correlation between income and the continuation of professional dynasties. In the works of this author, it is shown that with a decrease in status positions and a drop in the profitability of the profession, the tendency to continue the professional dynasty decreases (Mocetti, 2016).

\section{Professional continuity in the family assessment by educational and medicine employees}

\footnotetext{
${ }^{1}$ https://wciom.ru/database/baza_rezultatov_oprosa_s_1992_goda/
} 
Let us now consider the results of studies in 2017-2018 among teachers and doctors of state institutions of large cities in Russia. According to Rosstat (Russian Statistics), at the beginning of 2018, 12.5 million people lived in Moscow, 1.2 million people in Kazan, and 1.1 million people in Rostov-on-Don.

According to the survey materials, school teachers most often would not recommend their children choose the teacher profession. Most of all, this is typical for Rostov-on-Don (74\%) and Kazan (64\%) teachers. Among metropolitan teachers, this indicator is $51 \%$. Moreover, a relationship is revealed between assessing the degree of prestige of the place of work and the desire for professional continuity in the family. In the Moscow subgroup, the highest percentage of indications that the teaching profession is valued in society $(58 \%)$ and about half of the capital's teachers would recommend their children choose this profession. In Kazan, this ratio between assessing the prestige of the profession and the desire for family continuity is $43 \%$ and $36 \%$, in Rostov-on-Don - $26 \%$ and $26 \%$ (Table 1 ).

This circumstance is explained by the significant difference in the remuneration of school teachers in the capital and regional large cities of Russia. According to official figures, the average salary in the capital of the Russian Federation is 2 times higher than in the regions. Also, teacher pay in Kazan is about 25\% higher than in Rostov-on-Don (Volchik et al, 2018). At the same time, the conditionality of attitudes toward labor succession in the family by career prospects in the profession is not revealed (Table 1).

Table 1. Teachers' answers to the question "To what extend do you agree with the following statements?" (SFedU survey, 2017-2018, in\%)

\begin{tabular}{|l|c|c|c|c|c|c|}
\hline & \multicolumn{2}{|c|}{ Moscow } & \multicolumn{2}{c|}{ Kazan } & \multicolumn{2}{c|}{ Rostov-on-Don } \\
\cline { 2 - 7 } & disagree & agree & disagree & agree & disagree & agree \\
\hline $\begin{array}{l}\text { I would recommend } \\
\text { my children choose a } \\
\text { teacher profession }\end{array}$ & $\mathbf{5 1}$ & 49 & $\mathbf{6 4}$ & 36 & $\mathbf{7 5}$ & 26 \\
\hline $\begin{array}{l}\text { I think the teaching } \\
\text { profession is valued } \\
\text { in society }\end{array}$ & 42 & $\mathbf{5 8}$ & $\mathbf{5 7}$ & 43 & $\mathbf{7 4}$ & 26 \\
\hline $\begin{array}{l}\text { I am satisfied with } \\
\text { career prospects at } \\
\text { my work }\end{array}$ & 36 & $\mathbf{6 5}$ & 42 & $\mathbf{5 9}$ & 39 & $\mathbf{6 1}$ \\
\hline
\end{tabular}

In the field of healthcare, the assessment of the medical practice status is noticeably higher than in the teaching environment. There is also a correlation between doctors' assessment of the prestige of their work and the desire to see children as continuers of a professional dynasty. The highest rates for both positions are in Moscow subgroup of doctors, the lowest rate is in Rostov-on-Don. In the medical sphere, interregional income differentiation is also significant, when the highest salaries from the cities in question are fixed in Moscow and the lowest in the Rostov region. In general, according to official data, the income of school teachers is on average 30\% less than that doctors (Volchik et al, 2018). In addition, in the professional environment of doctors, there is a correlation between attitudes toward professional dynasty and satisfaction with the career prospects of respondents (Table 2).

Table 2. Doctors' answers to the question "To what extend do you agree with the following statements?” (SFedU survey, 2017-2018, in\%)

\begin{tabular}{|c|c|l|l|l|l|l|}
\hline \multirow{2}{*}{} & \multicolumn{2}{|c|}{ Moscow } & \multicolumn{2}{c|}{ Kazan } & \multicolumn{2}{c|}{ Rostov-on-Don } \\
\cline { 2 - 6 } & disagree & agree & disagree & agree & disagree & agree \\
\hline
\end{tabular}

\footnotetext{
${ }^{2}$ Hereinafter, the sum of the answer options "totally disagree" and "rather disagree", as well as "strongly agree" and "rather agree"
} 


\begin{tabular}{|l|c|c|c|c|c|c|}
\hline $\begin{array}{l}\text { I would recommend } \\
\text { my children choose a } \\
\text { doctor's profession }\end{array}$ & 33 & $\mathbf{6 7}$ & 44 & $\mathbf{5 6}$ & $\mathbf{6 0}$ & 40 \\
\hline $\begin{array}{l}\text { I think that the } \\
\text { profession of a } \\
\text { doctor is valued in } \\
\text { society }\end{array}$ & 24 & $\mathbf{7 6}$ & 31 & $\mathbf{6 8}$ & 51 & $\mathbf{5 0}$ \\
\hline $\begin{array}{l}\text { I am satisfied with } \\
\text { career prospects at } \\
\text { my work }\end{array}$ & 29 & $\mathbf{7 1}$ & 34 & $\mathbf{6 6}$ & 47 & $\mathbf{5 3}$ \\
\hline
\end{tabular}

\section{Conclusion}

An analysis of the professional dynasties perception by various subgroups of Russian society population shows that among Russians the attitude toward professional continuity in the family is not popular, although the very phenomenon of professional dynasties is generally assessed positively. Against this background, a subgroup of the population appears in the amount of from a quarter to a third of all the respondents who indicate their desire or the desire of their parents to inherit professional status. Most often, they share the attitude towards the continuation of family traditions in the professional sphere by representatives of higher-paid professional groups (lawyers, programmers, representatives of the extraction and processing of raw materials, telecommunications and communications, construction and real estate).

Based on the research materials of education and medicine workers, the dependence is confirmed that, with a decrease in status positions and a drop in the profitability of the profession, orientations toward continuing professional continuity in the family decrease. Namely, in the conditions of the existence of pronounced interregional differentiation of labor remuneration, Moscow doctors and teachers are more often oriented towards professional family continuity than doctors and teachers from regional large cities. As well as doctors, in comparison with school teachers, they value the prestige of their profession higher and, accordingly, are more oriented towards labor dynasty.

Acknowledgements. The article is written with the assistance of Russian Science Foundation, Project № 18-19-00320.

\section{References}

1. Dunn, Thomas and Holtz-Eakin, Douglas, Financial capital, human capital, and the transition to self-employment: Evidence from intergenerational links, Journal of labor economics, 18(2), 282-305 (2000)

2. Sørensen, B. Jesper, Closure and exposure: Mechanisms in the intergenerational transmission of self-employment, The sociology of entrepreneurship, Emerald Group Publishing Limited, 83-124 (2000).

3. Pellizzari, Michele, Basso, Gaetano, Catania, Andrea, Labartino, Giovanna, Malacrino, Davide and Monti, Paola, Family ties in licensed professions in Italy (A report for the Fondazione Rodolfo Debenedetti, Milan, Fondazione Rodolfo Debenedetti, 2011)

4. Scoppa, Vincenzo, Intergenerational transfers of public sector jobs: a shred of evidence on nepotism, Public Choice, 141(1-2), 167-188 (2009). 
5. Aina, Carmen and Nicolett, Cheti, The intergenerational transmission of liberal professions: nepotism versus abilities, University of York, Department of Economics and Related Studies, (2014).

6. Aina, Carmen and Nicolett, Cheti, The intergenerational transmission of liberal professions, Labour Economics, 51, 108-120 (2018). Information on https://doi.org/10.1016/j.labeco.2017.12.003

7. Corak, Miles, and Piraino, Patrizio, The intergenerational transmission of employers, Journal of Labor Economics, 29(1), 37-68 (2011). Information on https://doi.org/10.1086/656371

8. Valery Mansurov, Engineering dynasty of Russia. [Inzhenernye dinastii Rossii] RSS, (Moscow 2017).

9. Ludmila Klimenko, and Oxana Posukhova, Societal determination of professional identity in Russian society, Opcion, 34(16), 104-114 (2018a).

10. Ludmila Klimenko, and Oxana Posukhova, Career orientations of socially important professional groups of russian megacities in conditions of precariatization process [Kar'ernye orientacii societal'no znachimyh professional'nyh grupp rossijskih megapolisov $v$ usloviyah prekariatizacii], Reforming Russia: Yearbook [Rossiya eformiruyushchayasya: ezhegodnik], ISRAS, Moscow, 16, 437-454 (2018b).

11. Russians don't want children to continue their profession. [Rossiyane ne hotyat, chtoby deti prodolzhali ih professiyu ]. Press release VCIOM [Press-vypusk VCIOM], 1654 (17.12.2010) available at: http://wciom.ru/index.php?id=236\&uid=1779

12. Mocetti, Sauro, Dynasties in professions and the role of rents and regulation: Evidence from Italian pharmacies Journal of Public Economics, 133, 1-10 (2016).

13. Vyacheslav Volchik, Ludmila Klimenko, and Oxana Posukhova, Socio-economic sustainable development and the precariat: a case study of three Russian cities, Entrepreneurship and Sustainability, 6(1), 411-428 (2018) 